\title{
External auditory canal osteoma
}

\author{
Mohammed Bahgat, ${ }^{1}$ Yassin Bahgat, ${ }^{1}$ Ahmed Bahgat, ${ }^{1}$ Samia Aly $^{2}$ \\ ${ }^{1}$ Department of ENT and Head \& Neck Surgery, Alexandria University Hospitals, Alexandria, Egypt \\ ${ }^{2}$ Department of Pathology, Alexandria University, Alexandria, Egypt
}

Correspondence to Dr Mohammed Bahgat, mybahgat18@hotmail.com

\section{DESCRIPTION}

A 40-year-old female patient presented with a progressive hearing loss in her right ear during the last 3 months. She did not have otorrhea or otalgia. She did not report any attack of vertigo or tinnitus. On physical examination, the right external auditory canal (EAC) was completely occluded by a hard mass, which was fixed and covered with wax. Pure tone audiometry revealed a severe conductive hearing loss in the right ear with normal hearing in the left ear.

CT of the temporal bone revealed a $1.7 \mathrm{~cm} \times 1.5 \mathrm{~cm}$-sized, ovoid bony mass completely filling and occluding the inner part of the right bony EAC (figure 1). Preliminary diagnosis of the right EAC osteoma was made. The decision was taken to remove the osteoma surgically. Through the postauricular approach, it was confirmed that the origin of the osteoma was the posterior wall of the EAC. Removal of the osteoma was performed through its pedicle to avoid recurrences. Histopathological examination of the removed mass was made to rule out other similar conditions. It showed fibrovascular canals, surrounded by bone lamellae and the diagnosis of right external auditory canal osteoma was confirmed (figure 2).

Osteoma in the EAC is an uncommon benign lesion, which presents as a solitary, unilateral and slow-growing pedunculated mass in the bony canal. ${ }^{1} 2$ It is usually

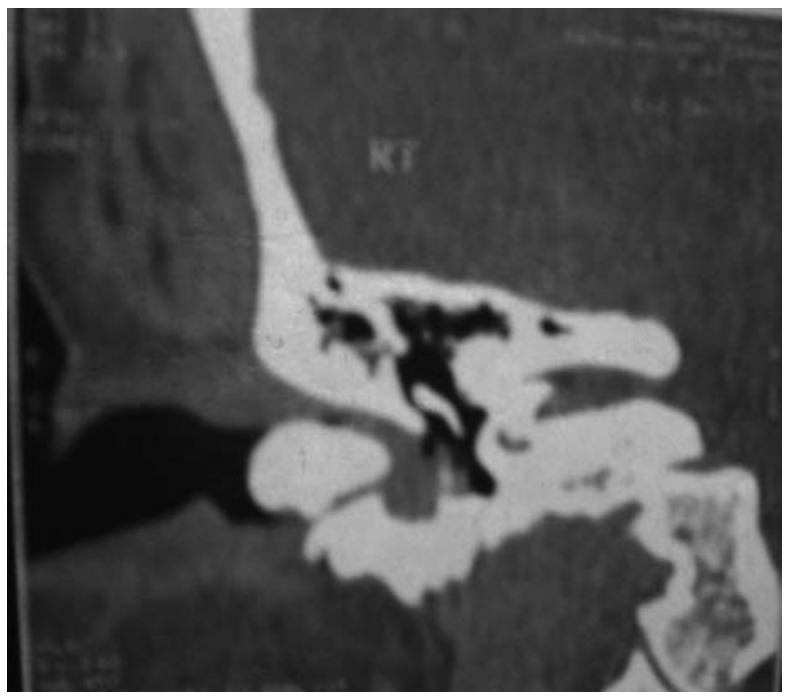

Figure 1 CT of the temporal bone showing $1.7 \mathrm{~cm} \times 1.5 \mathrm{~cm}$-sized, ovoid bony mass completely filling and occluding the inner part of the right bony external auditory canal.

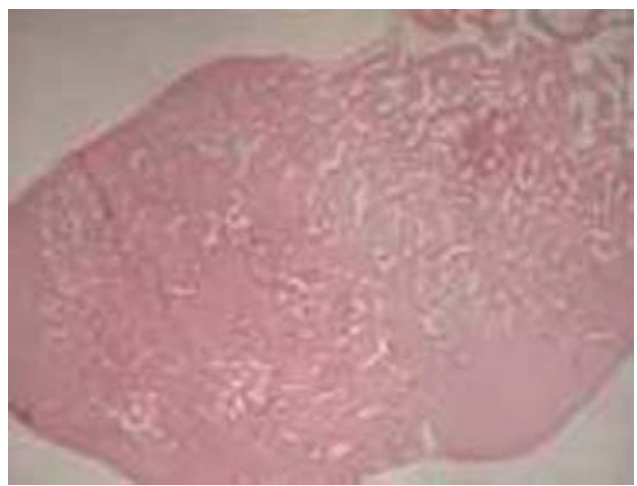

Figure 2 Histopathology of the removed mass showing fibrovascular canals, surrounded by bone lamellae. The diagnosis of osteoma was confirmed.

asymptomatic, but symptoms can arise if a canal obstruction occurs. ${ }^{2}$ Treatment of EAC osteoma is surgical removal through its pedicle to avoid recurrences. ${ }^{2}$

\section{Learning points}

- External auditory canal (EAC) osteoma is an uncommon benign lesion which is usually asymptomatic, but symptoms can arise if a canal obstruction occurs resulting in hearing loss.

- Diagnosis can be made by physical examination, which reveals the EAC completely occluded by a hard mass that may be covered by wax. Pure tone audiometry reveals a conductive hearing loss in the affected ear. CT of the temporal bone reveals a bony mass completely filling the bony EAC.

- Treatment of EAC osteoma is surgical removal through its pedicle to avoid recurrences. Histopathological examination of the removed mass is essential to rule out other similar conditions.

Competing interests None

Patient consent Obtained.

\section{REFERENCES}

1. Ebelhar AJ, Gadre AK. Osteoma of the external auditory canal. Ear Nose Throat J 2012;91:96-100.

2. Carbone PN, Nelson BL. External auditory osteoma. Head Neck Pathol 2012;6:244-6. 


\section{BMJ Case Reports}

This pdf has been created automatically from the final edited text and images.

Copyright 2012 BMJ Publishing Group. All rights reserved. For permission to reuse any of this content visit http://group.bmj.com/group/rights-licensing/permissions.

BMJ Case Report Fellows may re-use this article for personal use and teaching without any further permission.

Please cite this article as follows (you will need to access the article online to obtain the date of publication).

Bahgat M, Bahgat Y, Bahgat A, Aly S. External auditory canal osteoma. BMJ Case Reports 2012;10.1136/bcr-2012-006745, Published XXX

Become a Fellow of BMJ Case Reports today and you can:

- Submit as many cases as you like

- Enjoy fast sympathetic peer review and rapid publication of accepted articles

- Access all the published articles

- Re-use any of the published material for personal use and teaching without further permission

For information on Institutional Fellowships contact consortiasales@bmjgroup.com

Visit casereports.bmj.com for more articles like this and to become a Fellow 